\title{
Development of Cartoon Concept Based Student Worksheet with Structured Inquiry Approach to Train Science Process Skills
}

\author{
Nurul HIDAYATI ${ }^{1}$, Wahono WIDODO ${ }^{2}$, Nadi SUPRAPTO ${ }^{3}$, Husni MUBAROK ${ }^{4}$
}

\begin{tabular}{l} 
ARTICLE INFO \\
\hline Article History: \\
Received 19.03.2019 \\
Received in revised form \\
12.06 .2018 \\
Accepted \\
Available online 01.10 .2019
\end{tabular}

\begin{abstract}
The aims of this study are (1) to produce cartoon concept based student worksheet is valid, practical, and effective to train science process skills, (2) describe the validity, practicality, and effectiveness of cartoon concept based student worksheet to train process skills science. This research used development research with three stages, namely defining, designing, and developing. The results of expert validation state that the student worksheet is ready for use. Furthermore, it was tested on the fifth-grade students in Kedungdoro elementary school Surabaya with One Group Pretest-Posttest Design. The result of this research shows that (1) the cartoon concept based student worksheet is valid, because the readability assessment shows that the average number of words that can be completed by students is 73.13 from 81 words or $90.29 \%$, it indicates that the level of readability of student worksheet is high and easy to understand by students in learning. besides that the activities of students showed positive results, namely observing $13.37 \%$; make a hypothesis $14.17 \%$; experiment $13.06 \%$; measure $14.36 \%$; classify $12.20 \%$; interfere with $13.85 \%$, communicate $13.52 \%$; and conclude $13.75 \%$. (2) The cartoon concept based student worksheet can make the student's science process skills increase with the gain score is 0.80 .
\end{abstract}

C IJERE. All rights reserved

Keywords: ${ }^{1}$

Student Worksheet, Cartoon Concept, Structured Inquiry Approach, Science Process Skills .

\section{INTRODUCTION}

Science is a process that produces knowledge. The nature of science is the product, process, and application (technology), including the attitudes and values contained in it. The science products consisting of facts, concepts, principles, laws, and theories can be achieved through the use of scientific processes, namely through scientific methods or scientific methods, and scientific inquiry. In scientific inquiry and scientific methods are included in science process skills (Rustaman, 2014).

Science process skills are a set of skills used to do scientific investigations. Carin (In Rustaman, 2014) stated that there are several reasons for the importance of process skills. First, science in practice is inseparable from the scientific method, studying science not only on science material, but also understanding how to gather facts and link these facts to draw conclusions. Second, science skills are lifelong learning skills, it's not only used to learn science, but can also be used in everyday life, even to survive (life skills).

Science process skills are very important because science process skills are basic for solving problems in science and scientific methods (Wilujeng, 2010). In addition, science process skills are a skill needed to obtain, develop, and apply concepts, principles, laws, and theories of science consisting of intellectual, physical, and social skills (Rustaman, 2005). Djojosoediro (2010) said that science process skills teaching through science learning could be used as a vehicle for students to learn about themselves and their natural surroundings, and develop them in everyday life.

In order to be able to learn science well there are some basic skills that must be done and trained, namely observation and inference, measurement and estimation, asking questions and formulating problems, communication and interpretation, predictions and hypotheses, operational definitions, identification and control of variables and experiments and investigations (Rustaman, 2014). By developing process skills, students will be able to find and develop their own facts and concepts and grow and develop attitudes and values demanded (Semiawan, 1986)

\footnotetext{
Corresponding e-mail: nurul.17070855402@mhs.unesa.ac.id, orcid.org/0000-0002-3199-7697

${ }^{2}$ Corresponding e-mail: wahonowidodo@unesa.ac.id, scopus ID: 57191165275

3 Corresponding e-mail: nadisuprapto@unesa.ac.id, orcid.org/0000-0002-8990-7412

${ }^{4}$ Corresponding e-mail: husnimubarok254@gmail.com, orcid.org/0000-0002-5558-8361

Universitas Negeri Surabaya ${ }^{1,2,3}$
} 
Hidayati,N.,Widodo,W., Suprapto,N. \& Mubarok, H. (2019). Development of cartoon concept based student worksheet with structured inquiry approach to train science process skills. International Journal of Educational Research Review,4(4),582-592.

In fact, learning process skills of students at the elementary school level are low. This is because learning is still results oriented rather than process. This is reinforced by research conducted by Wibowo (2014) which shows the results that almost all students observed cannot convey opinions or predictions on observations that have been made, and they cannot communicate the results of the discussions they have conducted. A similar study was also conducted by Azizah (2017), in the initial science process skills test the level of student mastery of science process skills was low with an average score is 38, it is still far below of the minimal completeness criteria (Score: 75)

In line with the two studies above, the pre-research results carried out on fifth-grade students in Kedungdoro elementary school Surabaya amounted to 32 students, indicating that the mastery level of student's science process skills was low with grade 35 average scores, still far below of the minimal completeness criteria (Score: 75). The percentage of achievement of process skills obtained is also still low with an average of 35\%. With the following details are formulate a hypothesis: $63 \%$, observe: 59\%, communicate: $56 \%$, measure/calculate: $41 \%$, classification: $44 \%$, Inference and conclusions: $25 \%$, predict: $22 \%$, experiment: $21 \%$, and the lowest is classification: $9 \%$.

Based on these facts, innovative learning is needed to overcome the low level of science process skills, among other ways by improving the quality of learning, teacher competence, a conducive and adequate learning environment. The development of science process skills can be done by the teacher by using the constructivism approach, namely the inquiry approach. In inquiry teaching, there is a mental process. These mental processes include formulating problems, formulating hypotheses, designing experiments, conducting experiments, collecting and analyzing data and drawing conclusions (Rustaman, 2005).

This study used structured inquiry, a structured inquiry approach is right for learning elementary school age children, who still need guidance at each stage of inquiry and still have little experience in inquiry. The structured inquiry approach influences students' science process skills. This is reinforced by research conducted by (Zakiyah, 2011) in his research titled "The Influence of a Structured Inquiry Approach on Science Process Skills of Students on the Concept of Human Respiratory Systems" which shows that there is an influence of structured inquiry approaches to students' science process skills, and those who get grades the highest is observing skills. Similar research was also conducted by Hartati (2015) which showed that structured inquiry learning and 5E learning cycles had the same potential in improving science process skills and cognitive learning outcomes of students.

In the structured inquiry learning model, students are active in the knowledge discovery process through experimentation with the guidelines for student worksheet that have provided problem formulation, research tools, and materials, and research procedures, while the students' assignments conclude the results of research starts from problem determination, formulating hypotheses, carrying out research, processing data, analyzing data, and testing hypotheses.

Student worksheet is needed by students to train students' independence in their performance during learning. With the use of Student worksheet, they are more active and easier to understand learning material without the teacher's role being too dominant, the teacher is responsible for monitoring during the activity. During this time the Student worksheet used by the teacher is not the result of the teacher's own thoughts, but the results of other people, and more towards the cognitive, namely the discussion of practice questions. Because of that, the development of Student worksheet is more interesting and in accordance with the objectives of the 2013 curriculum is very necessary, so that not only does the mastery of students' concepts develop, but also expected to develop students' skills in scientific performance.

From the age of cognitive development, elementary students are still bound by concrete objects that can be captured by the five senses. So the material of science will be difficult to understand by students if taught conventionally because it has not caused students' imagination to matter. In fifth-grade elementary school science learning at Basic Competence "Applying the concept of heat transfer in everyday life" is still abstract in nature for student, they have many difficulties in understanding heat transfer events (conduction, convection, and radiation). Students only memorize examples of conduction, convection, radiation events given by the teacher or those in the textbook, but have not yet understood how conduction, convection, and radiation events can occur. Therefore in learning it requires media or props to visualize concepts that are still 
abstract. Visual media that can make children interested in science, one of which is cartoon media. According to Sudjana (2002) cartoons have the power to influence students' minds, lies in their compactness, simplification of content and attention that can be generated through images with a strong visual impact.

In this study, student worksheet will be developed which is presented in a form of cartoons that are easy to understand, so that students enjoy science learning more and can train students' science process skills. Learning with cartoons is included in the use of visual-based media that can improve understanding and strengthen memory. Visual media can also foster student interest and connect material with the real world. In the Journal of educations and Learning, Balim et al. (2016) state that: "Concept cartoons provide alternative views and help students at problem solving stage". This shows that concept cartoons as alternative learning media can improve students' abilities in the problem solving phase.

Some of the results of research that support these statements include Ören and Meriç (2014), published in the International Journal of Education in Mathematics, Science and Technology, which shows that learning using concept cartoons is more fun, students' understanding is deeper and students can remember learning more in science and technology. Another study conducted by Michaela Minarechova (2016) published in the European Journal of Science and Mathematics Education shows that the use of concept cartoons in science learning can develop students' ideas on natural phenomena.

Currently, the student worksheet offered by publishers and circulating in schools has several advantages and disadvantages. The advantages of the student worksheet include helping students understand learning material, making students better prepared in classroom learning, helping the learning process take place for teachers and students. While the disadvantages include making teachers lazy to teach by giving assignments to the student worksheet, the teacher is lazy to make questions. Besides that, there are contents of the student worksheet that are not in accordance with the material, monotonous and boring learning because students are only required to answer questions on the student worksheet.

Based on these descriptions, the researchers tried to develop a cartoon concept based student worksheet with structured inquiry approach to heat transfer material. The student worksheet developed not only maximizes cognitive understanding, but also student's science process skills.

\section{METHOD}

This study using development research by 4-D models. Develops cartoon concept based student worksheet with structured inquiry approach to train science process skills of students' fifth-grade on the heat transfer material. The participants were selected via "random sampling" method. The partiucipants of the research included 15 students in fifth grade at Kedungdoro IV Elementary School consist of 7 female and 8 male. The sample features was shown at Table 1.

Table 1. The Sample Features Of The Research

\begin{tabular}{ccccc}
\hline No & Name & Age & Gender & School \\
\hline $\mathbf{1}$ & ALZ & 11 th & Female & SDN Kedungdoro IV Surabaya \\
\hline $\mathbf{2}$ & AVR & 11 th & Female & SDN Kedungdoro IV Surabaya \\
\hline $\mathbf{3}$ & HSN & 11 th & Female & SDN Kedungdoro IV Surabaya \\
\hline $\mathbf{4}$ & FIR & 11 th & Male & SDN Kedungdoro IV Surabaya \\
\hline $\mathbf{5}$ & FIT & 11 th & Female & SDN Kedungdoro IV Surabaya \\
\hline $\mathbf{6}$ & GST & 11 th & Male & SDN Kedungdoro IV Surabaya \\
\hline $\mathbf{7}$ & GLG & 11 th & Male & SDN Kedungdoro IV Surabaya \\
\hline $\mathbf{8}$ & JNK & 11 th & Female & SDN Kedungdoro IV Surabaya \\
\hline $\mathbf{9}$ & VRL & 11 th & Male & SDN Kedungdoro IV Surabaya \\
\hline
\end{tabular}


Hidayati,N.,Widodo,W., Suprapto,N. \& Mubarok, H. (2019). Development of cartoon concept based student worksheet with structured inquiry approach to train science process skills. International Journal of Educational Research Review,4(4),582-592.

\begin{tabular}{cccll}
\hline $\mathbf{1 0}$ & MHS & 11 th & Male & SDN Kedungdoro IV Surabaya \\
\hline $\mathbf{1 1}$ & WHY & 11 th & Male & SDN Kedungdoro IV Surabaya \\
\hline $\mathbf{1 2}$ & FJR & 10 th & Male & SDN Kedungdoro IV Surabaya \\
\hline $\mathbf{1 3}$ & RZA & 10 th & Male & SDN Kedungdoro IV Surabaya \\
\hline $\mathbf{1 4}$ & SFA & 11 th & Female & SDN Kedungdoro IV Surabaya \\
\hline $\mathbf{1 5}$ & VIR & 11 th & Female & SDN Kedungdoro IV Surabaya \\
\hline
\end{tabular}

The student worksheet trial developed using One Group Pretest-Posttest Design. The trial design used one group to be given a pretest and given posttest after being treated. The research design by Fraenkel (2012) is described as follows:

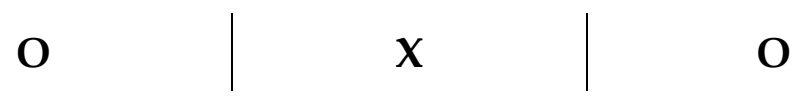

Information:

Figure 1. Design of Research with One Group Pretest-posttest Design

$\mathbf{0}=$ pretest and posttest process skills

$\mathrm{X}=$ treatment by using cartoon concept based student worksheet with structured inquiry approach.

Data from research results analyzed include device validity, process skills tests, observation sheets, student activity sheets, and the obstacles on the learning process.
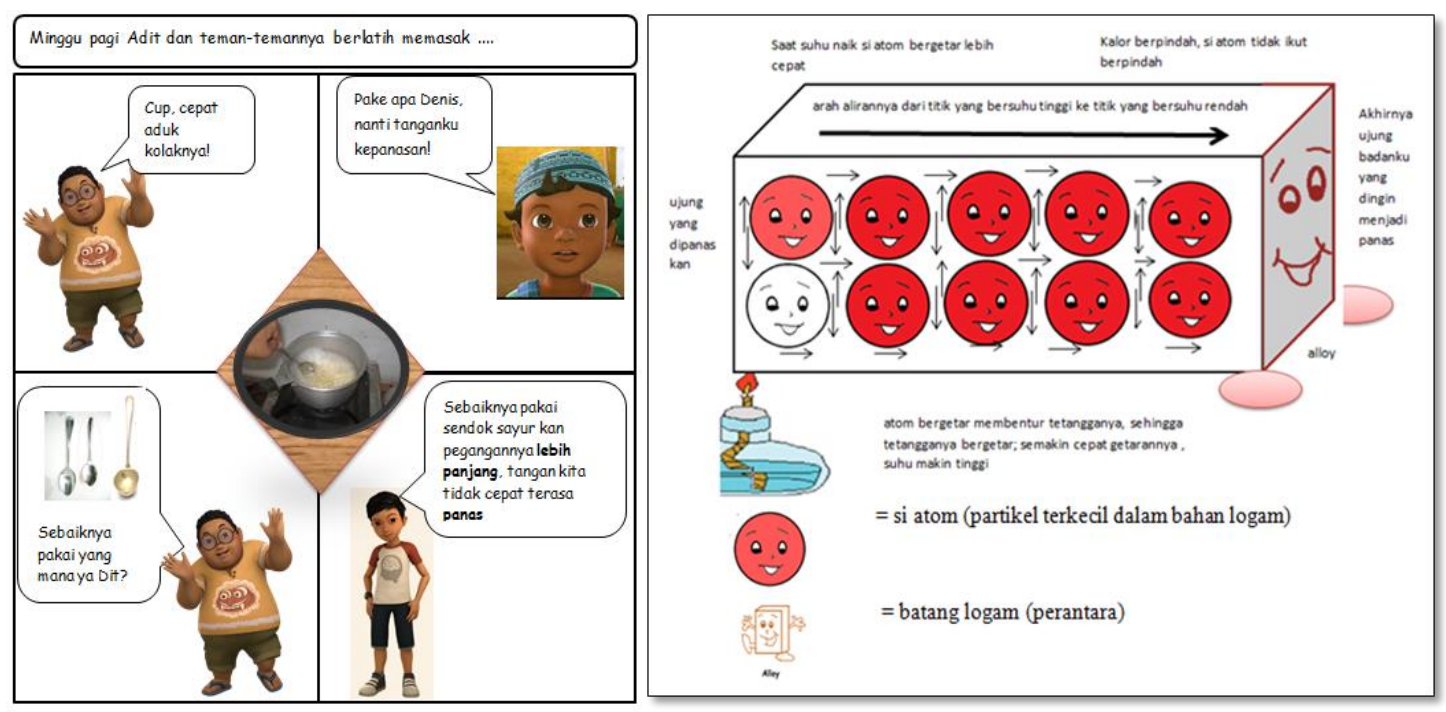

Figure 2. Examples of scenarios and concept cartoons in learning

\section{Analysis of Cartoon Concept Based Student Worksheet Validation Results}

Cartoon concept based student worksheet with structured inquiry approach that has been developed will be validated by the validator by providing an assessment of the correctness of the student worksheet concept. The assessment scale of the student worksheet validation devices into 1-4 scores, like Table 2 for more detail (Ratumanan and Lourens, 2006):

Table 2. Validity Criteria for the Cartoon Concept Based Student Worksheet

\begin{tabular}{ccl}
\hline Score Interval & Category & \multicolumn{1}{c}{ Information } \\
\hline $3,6 \leq \mathrm{P} \leq 4,0$ & Very valid & Can be used without revision \\
\hline $2,6 \leq \mathrm{P} \leq 3,5$ & Valid & Can be used with a minor revision \\
\hline $1,6 \leq \mathrm{P} \leq 2,5$ & less valid & Can be used with major revisions \\
\hline $1,0 \leq \mathrm{P} \leq 1,5$ & Invalid & Cannot be used yet \\
\hline
\end{tabular}


Hidayati,N.,Widodo,W., Suprapto,N. \& Mubarok, H. (2019). Development of cartoon concept based student worksheet with structured inquiry approach to train science process skills. International Journal of Educational Research Review,4(4),582-592.

\section{Analysis of Student Worksheet Readability Levels}

Measurement of the readability level analysis about cartoon concept based student worksheet with structured inquiry approach is done by calculating the percentage of the sentences numbers that can be supplemented by the total number of sentences that must be completed in the student worksheet. This analysis is calculated using by a formula like the following:

Information:

$$
\mathrm{P}=\frac{\sum K}{\sum N} \times 100 \%
$$

$\mathrm{P} \quad=$ Readability percentage

$\sum K=$ Number of sentences that can be completed

$\sum \mathrm{N}=$ Number of all sentences that must be completed

Criteria for percentage readability of about cartoon concept based student worksheet with structured inquiry approach are (Riduwan, 2012):

Table 3. Criteria for Reading Cartoon Concept Based Student Worksheet

\begin{tabular}{cc}
\hline Percentage & Category \\
\hline $81 \%-100 \%$ & Very easy to understand \\
\hline $61 \%-80 \%$ & Easy to understand \\
\hline $41 \%-60 \%$ & Quite easy to understand \\
\hline $21 \%-40 \%$ & Less easy to understand \\
\hline $0 \%-20 \%$ & Can not be understand \\
\hline
\end{tabular}

From Table 3, it can be said that a cartoon concept based student worksheet with structured inquiry approach can be understood if the level of readability reaches a minimum of $61 \%$.

\section{Analysis of Lesson Plan Implementation}

Analysis of learning implementation is an assessment of the feasibility of a lesson plan using the cartoon concept based student worksheet with structured inquiry approach. This assessment is carried out by two observers by giving a checklist $(\sqrt{ })$ in the available columns with a range of scores 1-4. The scoring guidelines are:

$1=$ if it is not implemented

$2=$ implemented but not finished

$3=$ implemented but still not right

4 = implemented, completed, and systematic

The results of learning implementation observations were analyzed by using qualitative descriptive analysis with the percentage of agreement formula. The instrument is good (reliable) if the reliability value is $>0.75$. Calculation of reliability of student activities is calculated by using the Borich formula (Ibrahim, 2005) as follows:

$$
\mathrm{R}=\left[1-\frac{A-B}{A+B}\right] \times 100 \%
$$

Information:

$\mathrm{R}=$ Instrument Reliability

$\mathrm{A}=$ Frequency of aspects with high values from both validators

$\mathrm{B}=$ Frequency of aspects with low values from both validators

\section{Analysis of Student Activities}

Analysis of student activity is activity data seen during learning. The percentage of student activity is measured quantitatively by the following formula (Akbar, 2013):

Information:

$$
\text { Persentase Aktivitas }=\frac{T_{S e}}{N} \times 100 \%
$$


Hidayati,N.,Widodo,W., Suprapto,N. \& Mubarok, H. (2019). Development of cartoon concept based student worksheet with structured inquiry approach to train science process skills. International Journal of Educational Research Review,4(4),582-592.

Tse $=$ number of activities shown by students

$\mathrm{N}=$ number of all activities

Student activity categories after according to Arikunto (2013)

Table 4. Student Activity Categories

\begin{tabular}{cc}
\hline Percentage & Category \\
\hline $76 \%-100 \%$ & High \\
\hline $56 \%-75 \%$ & Medium \\
\hline $40 \%-55 \%$ & Less \\
\hline$<40 \%$ & Low \\
\hline
\end{tabular}

\section{Analysis of Obstacles Encountered}

The obstacles of learning using cartoon concept based student worksheet with structured inquiry approach are analyzed descriptively, where the observer and the researcher make notes about the difficulties that occur during the implementation of learning. Besides that, the observers also provide input that used as a material to improve learning. Learning by using cartoon concept based student worksheet with structured inquiry approach is said to work well if these obstacles can be overcome.

\section{Analysis of Student Process Skill Test Results}

Individual student scores are scores obtained from students divided by maximum scores then multiplied by 100. Analysis of student process skills is the completeness of each student in all aspects of the process skills and completeness of each process skill. This analysis refers to the minimum completeness criteria at the school.

Improved process skills were analyzed by using the gain score between the pretest and posttest, to calculate the gain score using the Hake formula as follows (Hake,1999):

$$
g=\frac{\text { Spost-Spre }}{\text { Smax-Spre }}
$$

Information:

$\mathrm{g}$ (gain) $=$ increasing student process skills

Spre $=$ pretest score

Spost $=$ posttest score

Smax = maximum score

Obtaining criteria of gain score can be seen in Table 5:

Table 5. Criteria for Gain Score

\begin{tabular}{cc}
\hline Score Interval & Category \\
\hline $\mathrm{g} \geq 0,7$ & High \\
\hline $0,7 \geq 0,3$ & Medium \\
\hline $\mathrm{g} \leq 0,3$ & Low \\
\hline
\end{tabular}

\section{RESULT}

The readability test of student worksheet by completing overlapping sentences using words that is in accordance with the student worksheet, so that the student worksheet can be read. The readability of the cartoon concept based student worksheet is shown in the following Table 6.

Table 6. Results of Cartoon Concept Based Student Worksheet Readings 


\begin{tabular}{ccccc}
\hline No. & Name & $\begin{array}{c}\text { Number of words that } \\
\text { can be completed }\end{array}$ & $\begin{array}{c}\text { Number of words that } \\
\text { must be completed }\end{array}$ & $\begin{array}{c}\text { Readability } \\
\text { Percentage (\%) }\end{array}$ \\
\hline $\mathbf{1}$ & ALZ & 75 & 81 & 92,59 \\
\hline $\mathbf{2}$ & AVR & 74 & 81 & 91,36 \\
\hline $\mathbf{3}$ & HSN & 68 & 81 & 83,95 \\
\hline $\mathbf{4}$ & FIR & 70 & 81 & 86,42 \\
\hline $\mathbf{5}$ & FIT & 70 & 81 & 86,42 \\
\hline $\mathbf{6}$ & GST & 66 & 81 & 81,48 \\
\hline $\mathbf{7}$ & GLG & 73 & 81 & 90,12 \\
\hline $\mathbf{8}$ & JNK & 75 & 81 & 92,59 \\
\hline $\mathbf{9}$ & VRL & 76 & 81 & 93,83 \\
\hline $\mathbf{1 0}$ & MHS & 80 & 81 & 98,77 \\
\hline $\mathbf{1 1}$ & WHY & 78 & 81 & 96,30 \\
\hline $\mathbf{1 2}$ & FJR & 65 & 81 & 80,25 \\
\hline $\mathbf{1 3}$ & RZA & 79 & 81 & 97,53 \\
\hline $\mathbf{1 4}$ & SFA & 79 & 81 & 97,53 \\
\hline $\mathbf{1 5}$ & VIR & 69 & 81 & 85,19 \\
\hline & Average & 73,13 & & 90,29 \\
\hline
\end{tabular}

Based on the Table 5 the assessment results of the student worksheet readability show the average number of words that can be completed by students is 73.13 of 81 words or $90.29 \%$. This shows that the level of readability of the cartoon concept based student worksheet is high (easy to understand).

The implementation level of lesson plan reached $96.4 \%$. The detail results of student activities observations can be seen in the following Table 7.

Table 7. Observation Results of Student Activities

\begin{tabular}{|c|c|c|c|c|c|c|c|c|}
\hline \multirow{3}{*}{ No } & \multirow{3}{*}{ Observed Aspects } & \multicolumn{6}{|c|}{ Percentage of each meeting } & \multirow{3}{*}{$\begin{array}{c}\text { Average } \\
\text { Aspect } \\
(\%)\end{array}$} \\
\hline & & \multicolumn{2}{|c|}{1} & \multicolumn{2}{|c|}{2} & \multicolumn{2}{|c|}{3} & \\
\hline & & $\begin{array}{l}\text { P1 } \\
\text { (\%) }\end{array}$ & $\begin{array}{l}\text { P2 } \\
\text { (\%) }\end{array}$ & $\begin{array}{l}\text { P1 } \\
(\%)\end{array}$ & $\begin{array}{c}\text { P2 } \\
\text { (\%) }\end{array}$ & $\begin{array}{c}\text { P1 } \\
\text { (\%) }\end{array}$ & $\begin{array}{c}\text { P2 } \\
\text { (\%) }\end{array}$ & \\
\hline 1 & Observing & 12,18 & 12,30 & 13,61 & 13,91 & 13,61 & 13,39 & 13,37 \\
\hline 2 & Make hypothesis & 13,08 & 13,88 & 14,62 & 14,45 & 14,62 & 14,38 & 14,17 \\
\hline 3 & Measuring & 13,24 & 13,08 & 14,80 & 14,98 & 14,80 & 15,27 & 14,36 \\
\hline 4 & Classifying & 12,27 & 12,12 & - & - & - & - & 12,20 \\
\hline 5 & Conduct Experiment & 11,63 & 11,48 & 13,72 & 13,91 & 13,72 & 13,91 & 13,06 \\
\hline 6 & Referencing & 12,79 & 12,63 & 14,51 & 14,34 & 14,51 & 14,34 & 13,85 \\
\hline 7 & Communicating & 12,21 & 12,06 & 14,30 & 14,13 & 14,30 & 14,13 & 13,52 \\
\hline 8 & Concluding & 12,60 & 12,45 & 14,44 & 14,27 & 14,44 & 14,27 & 13,75 \\
\hline & total & 100 & 100 & 100 & 100 & 100 & 100 & \\
\hline & Reliability & \multicolumn{2}{|c|}{$81,25 \%$} & \multicolumn{2}{|c|}{$86,63 \%$} & \multicolumn{2}{|c|}{$85,13 \%$} & \\
\hline
\end{tabular}

Student activities showed positive results, namely observing $13.37 \%$; make hypothesis $14.17 \%$; measuring $14.36 \%$ conduct experiment $13.06 \%$; classifying $12.20 \%$; referencing $13.85 \%$, and communicating $13.52 \%$; concluding $13.75 \%$. It can be concluded that the cartoon concept based student worksheet is valid and can used to train the science process skills of fifth-grade students on "Heat Transfer" material.

Students are complete in the science process skills test if they obtain a minimum score are 75 . The results of the pretest and posttest show the completeness of the individual obtained during the trial, it can be seen in Table 8. 
Table 8. Completeness of Science Process Skills

\begin{tabular}{|c|c|c|c|c|c|c|}
\hline \multirow[b]{2}{*}{ Name } & \multicolumn{5}{|c|}{ Result } & \multirow[b]{2}{*}{ Completeness } \\
\hline & Pretest & $\begin{array}{c}\text { Minimal } \\
\text { Completeness } \\
\text { Criteria }\end{array}$ & Completeness & Postest & $\begin{array}{c}\text { Minimal } \\
\text { Completeness } \\
\text { Criteria }\end{array}$ & \\
\hline ALZ & 69 & 75 & Not completed & 81 & 75 & Completed \\
\hline AVR & 25 & 75 & Not completed & 88 & 75 & Completed \\
\hline $\mathrm{HSN}$ & 25 & 75 & Not completed & 75 & 75 & Completed \\
\hline FIR & 19 & 75 & Not completed & 88 & 75 & Completed \\
\hline FIT & 25 & 75 & Not completed & 88 & 75 & Completed \\
\hline GST & 56 & 75 & Not completed & 81 & 75 & Completed \\
\hline GLG & 38 & 75 & Not completed & 88 & 75 & Completed \\
\hline JNK & 38 & 75 & Not completed & 94 & 75 & Completed \\
\hline VRL & 63 & 75 & Not completed & 94 & 75 & Completed \\
\hline MHS & 63 & 75 & Not completed & 100 & 75 & Completed \\
\hline WHY & 38 & 75 & Not completed & 88 & 75 & Completed \\
\hline FJR & 63 & 75 & Not completed & 88 & 75 & Completed \\
\hline ALZ & 44 & 75 & Not completed & 94 & 75 & Completed \\
\hline AVR & 56 & 75 & Not completed & 81 & 75 & completed \\
\hline $\mathrm{HSN}$ & 44 & 75 & Not completed & 88 & 75 & Completed \\
\hline Total & 663 & & & 1316 & & \\
\hline Average & 44 & & & 88 & & \\
\hline
\end{tabular}

The results of the science process skill test show that the average score of the pretest from 15 students is 44 and no students have achieved mastery. The posttest average score is 88 with all students achieving completeness.

The measurement of improvement in learning outcomes can be done by calculating the gain score. The gain score from the pretest and posttest results can be seen in Table 9.

Table 9. Gain Scores of Science Process Skills

\begin{tabular}{|c|c|c|c|c|}
\hline \multirow{2}{*}{ Name } & \multicolumn{2}{|c|}{ Result } & \multirow{2}{*}{ Gain } & \multirow{2}{*}{ Category } \\
\hline & Pretest & Posttest & & \\
\hline ALZ & 69 & 81 & 0,39 & Medium \\
\hline AVR & 25 & 88 & 0,84 & High \\
\hline HSN & 25 & 75 & 0,67 & Medium \\
\hline FIR & 19 & 88 & 0,85 & High \\
\hline FIT & 25 & 88 & 0,84 & High \\
\hline GST & 56 & 81 & 0,57 & Medium \\
\hline GLG & 38 & 88 & 0,81 & High \\
\hline JNK & 38 & 94 & 0,90 & High \\
\hline VRL & 63 & 94 & 0,84 & High \\
\hline MHS & 63 & 100 & 1,00 & High \\
\hline WHY & 38 & 88 & 0,81 & High \\
\hline FJR & 63 & 88 & 0,68 & Medium \\
\hline ALZ & 44 & 94 & 0,89 & High \\
\hline AVR & 56 & 81 & 0,57 & Medium \\
\hline
\end{tabular}




\begin{tabular}{ccccc}
\hline HSN & 44 & 88 & 0,79 & High \\
\hline Total & 663 & 1361 & & \\
\hline Average & 44 & 88 & 0,80 & High \\
\hline
\end{tabular}

The gain score for each aspect of the process skills obtained can be seen in Table 10 .

Table 10. Score Gain for Each Aspect of Science Process Skills

\begin{tabular}{cccccc}
\hline \multirow{2}{*}{ No } & \multirow{2}{*}{ Process Skills } & \multicolumn{2}{c}{ Result } & \multirow{2}{*}{ Gain } & \multirow{2}{*}{ Category } \\
\cline { 3 - 4 } & & Pretest & Posttest & & \\
\hline 1 & Observing & 43 & 80 & 0,65 & High \\
\hline 2 & Make hypothesis & 40 & 97 & 0,95 & High \\
\hline 3 & Measuring & 27 & 77 & 0,68 & High \\
\hline 4 & Classifying & 43 & 83 & 0,70 & High \\
\hline 5 & Conduct Experiment & 33 & 80 & 0,70 & High \\
\hline 6 & Referencing & 37 & 83 & 0,73 & High \\
\hline 7 & Communicating & 57 & 100 & 1,00 & High \\
\hline 8 & Concluding & 73 & 100 & 1,00 & High \\
\hline & Total & 353 & 700 & 6,42 & \\
\hline & Average & 44 & 88 & 0,80 & High \\
\hline
\end{tabular}

The average gain score is 0.80 and belongs to the high category.

\section{DISCUSSION}

Student worksheet needs to be tested for readability to find out whether the student worksheet is feasible or not, and to determine the readability level of cartoon concept based student worksheet with the Structured Inquiry Model. Students complete the sentences (incomplete) with appropriate words, so that the cartoon concept based student worksheet with structured inquiry approach can be read.

The data in Table 5 shows that the results of the readability of the cartoon concept based student worksheet with structured inquiry approach are the average number of words that can be completed by students is 73.13 out of 81 words or $90.29 \%$. This shows that the cartoon concept based student worksheet with structured inquiry approach has a high level of readability and is easy for students to understand so that it can be used in the learning process in the classroom.

The student worksheet can be used by fifth-grade students of elementary school because it is arranged by considering linguistic factors. Teaching materials have the main aspects, one of which is linguistic aspects (Nur, 2008). The linguistic or readability aspects include using Indonesian language in accordance with EYD, terminology, clear language, appropriate language, and easy to read.

Observation of learning implementation in limited trial research was conducted by two observers who gave an assessment of the implementation of learning using cartoon concept based student worksheet. The implementation of observations includes initial activities, core activities, closing activities, time management, and classroom management. The level of implementation of the lesson plan reached $90.47 \%$. Based on these results it can be stated that the learning carried out by the teacher with using cartoon concept based student worksheet has gone well.

Activities observed in learning by using cartoon concept based student worksheet include process skills of observing, hypothesizing, calculating, classifying, inferring, and communicating. Based on Table 6, the lowest activity is the process skill of identification, that is, with the average emergence percentage reaching $12.20 \%$. The skill of making hypotheses has the lowest average appearance because students tend to be unfamiliar with the process skills. Activities that have the highest average occurrence are observed, which 
Hidayati,N.,Widodo,W., Suprapto,N. \& Mubarok, H. (2019). Development of cartoon concept based student worksheet with structured inquiry approach to train science process skills. International Journal of Educational Research Review,4(4),582-592.

reaches $14.36 \%$. Observation skills have the highest average because they include basic process activity skills that are easy and have often been done by students.

The results of the science process skill test show that the average score of the pretest of 15 students is 44 and no students had achieved mastery. The posttest average score is 88 with all students achieving completeness. The average score gain is 0.80 and belongs to the high category.

In Table 7 shows the completeness of each aspect of process skills, at the pretest it was seen that every aspect of process skills did not complete because it had not yet reached 75 (minimal completeness criteria) with an average value of 44 , whereas in posttest it seemed that completeness in each aspect of process skills with an average value of 88 had exceeded minimal completeness criteria (score: 75). The highest process skill is communicating and concluding with a score of 100 and conducting experiments with the lowest score is 77.

The data in Table 8 shows the gain scores for trained science process skills including the high category with an average value of 0.80 . This shows an increase from pretest scores to posttest scores of students' science process skills.

The overall science process skills are complete with an average gain score of 0.80 in the high category, this is because the activities of students related to science process skills include observing, making hypotheses, experimenting, measuring, influencing, classifying, communicating and concluding centered on student. In addition, the students using student worksheet which is presented in a cartoon form that is easy to understand, so that students enjoy learning science more and can train students' science process skills.

The results of gain scores of the high process skill test show that the cartoon concept based student worksheet with structured inquiry approach to train science process skill for fifth grade students at Heat Transfer material give encouragement to students to be active, so that the science process skills of students is increase.

\section{CONCLUSION}

The developed of cartoon concept based student worksheet has fulfilled the requirements of validity, practicality and effectiveness, and can overcome the obstacles on learning about terms that are still unfamiliar to students and not yet accustomed to conduct the experiments. The cartoon concept based student worksheet with structured inquiry approach can make the student's science process skills increase with the gain score is 0.80 .

Some suggestions that can be used in science learning in elementary schools include (1)science learning in primary schools can be implemented by applying concept cartoons based LKPD with structured inquiry models to train students' Science Process Skills (2)for further research, it is better that before the research students are given prior knowledge about science process skills so that students do not feel familiar with terms related to science process skills during the experiment.

\section{REFERENCES}

Akbar, S. (2013). Instrumen perangkat pembelajaran. Bandung: PT Remaja Rosdakarya.

Arikunto, S. (2013). Dasar-dasar evaluasi pendidikan. Jakarta: Bumi Aksara.

Azizah, K. (2017). Pengembangan lks berbasis pendekatan keterampilan proses untuk melatihkan keterampilan proses dan pemahaman konsep energi listrik kelas V SD. Makalah Komprehensif. Surabaya: Universitas Negeri Surabaya.

Balim, et.al. (2016). Concept cartoons supported problem based learning method in middle school science classroom. Journal of Eduation and Learning, 5 (2).

Banchi, H. \& Bell, R. (2008). The many levels of inquiry. Education Resources Information Center, 46 (2), $26-29$. 
Hidayati,N.,Widodo,W., Suprapto,N. \& Mubarok, H. (2019). Development of cartoon concept based student worksheet with structured inquiry approach to train science process skills. International Journal of Educational Research Review,4(4),582-592.

Djojosoediro, W. (2010). Hakikat IPA dan pembelajaran IPA di SD. Modul. Tidak diterbitkan.

Fraenkel, J. R. et.al. (2012). How to design and evaluate research in education. New York: McGraw-Hill.

Hake, R.R. (1999). Analyzing change gain scores. AREA-D American Education Research Association's Devision.D, Measurement and Research Methodology.

Hartati, Tri Asih Wahyu.dkk. (2015). Pengaruh model pembelajaran inkuiri terstruktur dan siklus belajar 5e terhadap keterampilan proses sains dan hasil belajar kognitif peserta didik pada kemampuan akademik berbeda. Jurnal Pendidikan Sains UM, 3 (1), 22-30.

Ibrahim, M. (2005). Assesmen berkelanjutan konsep dasar, tahapan, pengembangan, dan contoh. Surabaya: Unesa University Press.

Michaela, M. (2016). Using a concept cartoon method to address elementary school students' ideas about natural phenomena. European Journal of Science and Mathematics Education, 4 (2), 214-228.

Ören, F. Ş. \& Gülçin, M. (2014). Seventh grade students' perceptions of using concept cartoon in science and technology course. International Journal of Education in Mathematics, Science and Technology, 2 (2), 116136.

Ratumanan, T. G. \& Theresia, L. (2006). Evaluasi hasil belajar yang relevan dengan kurikulum berbasis kompetensi. Surabaya: Unesa University Press.

Riduwan. 2012. Skala pengukuran variabel-variabel penelitian. Bandung: Alfabeta.

Rustaman, N. Y. (2005). Strategi belajar mengajar biologi. Malang: IKIP Malang.

Rustaman, N. (2014). Materi dan pembelajaran IPA SD. Tangerang Selatan : Universitas Terbuka

Semiawan, C. (1986). Pendekatan keterampilan proses: bagaimana mengaktifkan siswa dalam belajar. Jakarta: PT. Gramedia.

Sudjana, N. \& Ahmad, R. (2002). Media pengajaran. Bandung: Sinar Baru Algensindo.

Wibowo, R. A. A. (2014). Meningkatkan keterampilan proses dasar IPA menggunakan pendekatan keterampilan proses pada siswa kelas IV SDN kiyaran II cangkringan sleman yogyakarta, http://eprint.uny.ac.id/, $16 / 10 / 2016$.

Wilujeng, I. A. S. \& Liliasari. (2010). Kompetensi IPA terintegrasi melalui pendekatan keterampilan prosesmahasiswa S1 pendidikan IPA. Jurnal Cakrawala Pendidikan (3), 14.

Zakiyah, N. (2011). Pengaruh pendekatan inkuiri terstruktur terhadap keterampilan proses sains siswa pada konsep sistem pernapasan manusia. Skripsi. Jakarta: Universitas Islam Negeri Syarif Hidayatullah. 